\title{
Defined Observation Result Type Code
}

National Cancer Institute

\section{Source}

National Cancer Institute. Defined Observation Result Type Code. NCI Thesaurus. Code C93785.

A coded value specifying the kind of observation result. 